\title{
NORMS AND POWER IN FIGURATIONAL SOCIOLOGY
}

\section{Aleksejs Šṇitṇikovs}

Dr. sc. soc.

\begin{abstract}
The purpose of this article is to highlight the strengths of conceptualisation of norms and power in figurational sociology and to identify some of its limitations. The founder of figurational sociology Norbert Elias, along with his theory of the civilizing process, created a number of middle-range concepts, which can be both theoretically interpreted and used in empirical research. His central concept was figuration, the bounded network of interdependent actors with the shifting power balance. Elias understood norms or rules as conventions, or prescriptions, which serve the purpose of coordination of interdependencies but at the same time closely tied to the distribution of power among the actors. Concepts such as formalisation and informalisation, duality of norms, established and outsiders make possible empirically grounded analysis of transformation of norms and their social functions. Research conducted in figurational perspective has contributed to the advance of sociological understanding of norms and power. At the same time in figurational sociology there is lack of recognition of autonomy and impact of ideological power, for instance, that religious or metaphysical doctrines can bring about changes in the norms of collectivities and habitus of the individuals.
\end{abstract}

Keywords: norms, power, figuration, development, interdependence, civilizing process, law, ideological power

\section{Introduction}

Norms and power are essential concepts of modern social theory, but their interpretations differ in contemporary theoretical syntheses. Some authors have argued that figurational sociology founded by Norbert Elias can be used as a basis for further development of social theory ${ }^{1}$. In this article, the author proposes that at least, conceptualisation of norms and power and their interrelationships in figurational sociology have certain strengths, notably, that in its framework these concepts can be theoretically

1 For example: Dunning, E., Hughes, J. (2013) Norbert Elias and Modern Sociology. London: Bloomsbury; Quilley, S., Loyal, S. (2005) Eliasian Sociology as a ‘Central Theory' for the Human Sciences, Current Sociology. Vol. 53(5), pp. 807-828. 
interpreted in a fairly consistent way and fruitfully applied in research of social problems.

It can be argued that in the works by Elias the concept of power has a more central role than the concept of norms or rules. He at times criticised the concept of norms, along with such concepts as structure or role for the way these were used in sociology contemporary to him because he considered that these are static abstractions of certain features of society at a particular stage of development ${ }^{2}$. He argued that the usage of the concept of norms contains elements of wishful thinking, especially in structural functionalism. Behaviour which is in conformity with norms is deemed to be 'good' and 'functional' for the maintenance of the social system, while violation of prevailing norms is viewed as anomic and dysfunctional. He considered power a more fundamental feature of human relationships and one of the key concepts for explanation of the transformation of societies. On the other hand, it can be said that the problem of normative regulation of behaviour was central in his studies of the civilizing process and later in his research on national identity. He sought to explain the patterns of behaviour in modern and pre-modern societies and used a number of terms for normative regulation. Habitus was the main concept in his studies of the civilizing process - the internalised constraints imposed by the social environment in forms of laws, rules and power relations. He also used the terms code of behaviour, tradition of behaviour and feeling in his later work on national identity, and the concept of rules in his more theoretical works.

Elias's figurational and process sociology was empirically and historically oriented. The concepts and middle-range theories, which he elaborated, are applicable to study of various social and historical settings and topics, including problems of norms and power, which can be seen in subsequent research in figurational perspective $e^{3}$. It is important to recognise the explanatory potential of theories and concepts developed in figurational sociology. However, it is also necessary not to overstretch their use and to identify their eventual limitations. As a matter of fact, Elias did not intend that his concepts and theories would constitute a closed system; on the contrary, he presupposed that they could be tested, corrected and improved.

2 Elias, N. (2000) The Civilizing Process. Oxford: Blackwell, p. 468.

3 Online journal Human Figurations published by Michigan University contains a large number of articles which use figurational perspective and may be referred to for information about contemporary research and discussions in figurational sociology: https://quod.lib.umich.edu/h/humfig?page = home 


\section{General conception of rules, norms and law}

Elias had stated clearly that he did not regard rules as invariant and necessary property of human relationships because one can observe relationships with few or no rules altogether - such as wars, revolutions, rebellions, massacres etc. In heated conflicts where opponents are very hostile to each other, there are no rules; these relationships are governed by the strategic action and cunning, each of the opponents trying to weaken or destroy the other. However, these relationships also are not devoid of any order - they are ordered in the sense that the actions of one party are determined by the expectation of the actions of another. This is an order ungoverned by predetermined or agreed rules, such as may be observed in nature. Elias noted that with the assumption that there cannot be human relationships without rules one cannot explain under what conditions rules arise. It can be said that Elias did not come to the overall explanation of the origins of rules, but from his "game models" and also from his work on the civilizing process it can be deduced that one of the preconditions for the rules, or norms, is existence of a more or less even power balance among the actors; another is interdependence among the actors, and an expectation that it will continue in the future ${ }^{4}$.

Elias considered interdependence among humans as the most basic fact of social life and also as the proper subject matter of sociology. Another important concept for him was power. People struggle for the desired place in the system of interdependencies; those who have greater power resources make others more dependent on them and have more possibilities to steer the behaviour of others. Modern societies are characterised by complex interdependence among groups and individuals and require more rules to regulate their interactions. People in societies of the past, such as feudal societies of the middle ages in Europe, were far less interdependent. There were far less rules applicable in the territories of the nascent, developing states and their enforcement was problematic and contested. That was especially so when decentralising, centrifugal tendencies became prevalent, as Elias shows on the example of medieval France. By receiving the grants of land and through making them their hereditary possessions, the feudal lords acquired the base for their independent power. The king became more dependent on his vassals than they were dependent on him. Consequently, his power to issue laws and to resolve disputes was very limited. At times, the king was confronted by his more powerful vassals and was unable to make them follow their feudal obligations. In the $12^{\text {th }}$ century, the King of England Henry II was formally

4 "Game models" are set forth in: Elias, N. (1978) What is sociology? New York: Columbia

University Press, pp. 71-103. 
the vassal of the King of France, but he was attaching more lands in France. That was the breach of homage, the promise of loyalty to his feudal lord against which the French king protested, but as Elias remarks, "“law" counts for little when it is not backed by corresponding social power" It was usual to resolve disputes over land by military means, and in this struggle, the decisive factor was the physical strength of the combatants. The kings were more able to impose the legal order and issue laws as the process of centralisation advanced from the $13^{\text {th }}$ century and the monopoly on the use of violence and taxation was gradually established. When society became more integrated and the central authority more stable, a legal order could be imposed in the territory. Elias stresses that it is the power of central authorities, which makes the laws valid and that the content of the legal norms reflects the power balance in the society: "Legal forms correspond at all times to the structure of society" The institutions of power embedded in the overall power structure of society make the law count, although, as Elias notes, there may arise an impression of the autonomous existence and functioning of the system of law. Law may operate relatively independently from the power structure of society, but finally it must be regarded as "a function and symbol of the social structure or - what comes to the same thing - the balance of social power"7. The law is not simply a tool of the dominant class and the expression of its will; the power position of any social group is more or less precarious and may be challenged. In historical process, there are changes in the power balances between the social groups and the legal norms express their changing power potentials. The power base of the king was the standing army and the monopoly on taxation (in France from $15^{\text {th }}$ century), but also the increasing need of social groups for central regulation and coordination ${ }^{8}$. Law was such means of societal coordination and, as economic interdependence of social groups was increasing, the central authority became regularly preoccupied with law-giving activity.

This general conceptualization of relationships between norms and power may seem quite simple, but it opens up possibilities for empirical investigations of changes of normative orders in connection with the changing forms of interdependence, needs for coordination, and power balance. In this respect, it has advantages in comparison to some influential theoretical syntheses in sociology, for example the theory of structuration by Anthony Giddens.

5 Elias, N. (2000) The Civilizing Process. Oxford: Blackwell, p. 283.

6 Ibid., p. 233.

7 Ibid., p. 234.

8 Ibid., p. 314. 
The concept of rules is an important one in Giddens's theory of structuration. Social life is permeated by rules, which are of two kinds syntactic rules governing the usage of language and moral rules, or norms, which are invoked in legitimisation and sanctioning of actions. Rules are general procedures of social practices and human actors are held accountable for following them. Moreover, tacit rules are no less important than discursively formulated rules, such as laws. Power also is an important concept, for Giddens considers that this is what actually constitutes agency - the ability to initiate changes in the objective world. Power is a transformative capacity, which draws upon resources in strategic action or in reproduction of institutions. However, the use of power presupposes the existence of structures - the sets of rules and resources ${ }^{9}$. Giddens emphasises the use of power in regularised and institutionalised social settings. Wars, violent confrontations and the threat of force are not the most far-reaching or typical cases of use of power in human history ${ }^{10}$. The process of structuration involves the application of interpretative schemes, moral rules and resources, in course of which the structural properties of social systems are in turn reconstituted. All social activity "implies the interlacing of meaning, normative elements and power"11. Such close linking of rules, norms and power in theory makes difficult the empirical analysis of their interrelationships. It is also doubtful that usefulness of these conceptualisations was demonstrated in Giddens's works on historical sociology ${ }^{12}$.

\section{Norms and power balance between social groups}

In his later works, Elias put forward a pluralistic conception of the development of society. According to this conception, at different historical phases, there have been different dominant groups and their power position was based on the importance of the function that they performed for the society at the particular stage of development ${ }^{13}$. In archaic

${ }^{9}$ Giddens, A. (1979) Central problems in social theory. Berkeley and Los Angeles: University of California Press, p. 107.

${ }^{10}$ Giddens, A. (1986) The Constitution of Society. Berkeley and Los Angeles: University of California Press, p. 257.

${ }^{11}$ Ibid., p. 28-29.

${ }^{12}$ Giddens, A. (1992) The Nation-State and Violence. Cambridge: Polity Press; Giddens, A. (1995) A contemporary critique of historical materialism. Second edition. Stanford: Stanford University Press.

${ }^{13}$ Pluralistic conception is presented in: Elias, N. (2009) The retreat of sociologists into the present. In: Essays III: On Sociology and the Humanities, Collected Works, vol. 16. Dublin: University College Dublin Press, pp. 107-126. 
societies, religious specialists, the priests, and warriors were the most powerful. The priests carried out cultic activities and possessed earlier forms of knowledge, but the warriors controlled the means of violence and performed the functions of defence of the survival unit and attack of other survival units. These two groups of specialists were competing with each other, but among most European peoples, the military specialists achieved dominance. The status and power position of the military specialists was higher than those of traders, merchants, financiers and labourers. However, towards the end of the middle ages the performance of the defence and attack function became more and more dependent on the services provided by the economic specialists. In the process of state formation, the warriors, the state officials, the merchants, financiers and entrepreneurs became increasingly interdependent. With the development of technologies, trade, and organisation of production, these specialists strengthened their power base and eventually obtained access to the political offices and became influential in the process of the political decision-making. These economic specialists, commanding the use of economic resources, came into conflict with the group providing the labour services - the class of workers. The number of interconnected processes - industrialisation, bureaucratisation, urbanisation and democratisation occurring in the $18^{\text {th }}$ and $19^{\text {th }}$ centuries changed the overall structure of society. The masses increased their power potential over against the ruling elites. The changes in the power ratios of the groups was usually a conflict-ridden process, the struggles between the employers and the workers were going on during the $19^{\text {th }}$ and the $20^{\text {th }}$ centuries $^{14}$. The class of controllers of the means of investment was unable to secure an undisputed position of dominance, nor was it possible for the labour. The working classes, thanks to their increasing significance for the functioning of the economic system and their organisation, succeeded in winning more social and political rights. As Elias puts: "The legal extension of franchise, often against strong resistance, was the manifest institutional consequence of the latent shift in the distribution of power towards broader strata"15.

Elias elaborates on the interrelations between power and norms on a more specific case of the relationships between the sexes in Ancient Rome. He writes that in the period of republic before the $2^{\text {nd }}$ century $\mathrm{BC}$ women were thoroughly subordinated to men and were under protection of their husbands or relatives. Women did not have the right to own property and

\footnotetext{
${ }^{14}$ Pluralistic conception is presented in: Elias, N. (2009) The retreat of sociologists into the present. In: Essays III: On Sociology and the Humanities, Collected Works, vol. 16. Dublin: University College Dublin Press, p. 123.

${ }^{15}$ Elias, N. (1978) What is Sociology? New York: Columbia University Press, p. 66.
} 
the right to divorce only men had such rights. It can be said that women were not considered independent subjects. However, around the $1^{\text {st }}$ century $\mathrm{BC}$ the situation changed. There appeared strata of wealthy citizens, who wanted to provide the means of material security for their daughters in case of divorce. When a woman from aristocratic family married, she was endowed with certain assets, which in the beginning were under control of the woman's male relatives, but later became the woman's property. Women obtained the right to divorce and in Rome, both men and women could do it. Thereby, women became equal to men with respect to marital life, even though in other spheres, such as public and political life, inequality remained. An important precondition of ensuring equality between men and women in marriage was a relatively strong state with the system of courts, which could judge impartially and effectively enforce decisions. Elias comments that norms are not entities floating above the humans, they are changing and these changes can be explained by shifting power balances: "[s]uch a norm can be understood and explained with the help of process-sociological reconstruction - that is a reconstruction of the preceding inequality of the partners and of the process that led from it to later equality. And since it is the shift in power between and within states or tribes that are at the centre of these processes, one could perhaps say more generally: norms change with power relations" 16 .

Elias identified the overall historical trend of reduction of differences of power potentials between social groups, which he called 'functional democratization' ${ }^{17}$. With the growing interdependence between the groups, there arises a parallel tendency toward reducing of power differentials between the elements of the chain of interdependence, and this brings about changes of norms. Functional democratisation is linked to informalisation. When the social distance between the groups is wide, the more powerful group tends to develop a more formalised code of behaviour, for example, a complex etiquette of the court, the high society or the corps of army officers. Formalised norms function as a mark of distinction, a symbolic differentiation between higher and lower strata ${ }^{18}$. When the power differentials between the groups decrease, there is a tendency of informalisation of norms - the behaviour becomes less standardised, observance of the rules of politeness becomes less strict, there is more

${ }^{16}$ Elias, N. (2009) The changing balance of power between the sexes - a processsociological study: example of the ancient Roman state. In: Essays III: On Sociology and the Humanities, Collected Works, vol. 16. Dublin: University College Dublin Press, p. $261 \mathrm{fn}$.

${ }^{17}$ Elias, N. (1978) What is Sociology? New York: Columbia University Press, p. 68.

${ }^{18}$ Elias, N. (1996) The Germans. New York: Columbia University Press, p. 72. 
laxity in expression of emotions. The process of informalisation can be observed in work environment, in relationships between the sexes and other contexts. Elias used the examples of the European societies, notably Germany, to show the operation of the processes of formalisation and informalisation. Substantial weakening or disintegration of the survival unit is likely to lead to a radical informalisation, the breakdown of a particular pattern of self-control; because it is the social group, which sustains the sense of meaning and makes the behavioural code binding ${ }^{19}$.

Sociologist Cas Wouters continued the studies of processes of the civilizing of manners beyond the age of absolutism. The codes of conduct of aristocracy and bourgeoisie in the $19^{\text {th }}$ century amalgamated and produced highly formalised manners. The observance of a strict and quite ritualistic code of behaviour was demanded from persons belonging to a 'good society' and was an indication of trustworthiness, which was important for the developing industrial market society. The code of conduct marked by strict self-control, punctuality and moral standards in private life was percolating also into the middle classes. In the $20^{\text {th }}$ century, as industrialisation continued, the economic life required more frequent contacts among people of different social background; the growing interdependence among various social groups meant that social distance had to decrease and the manners had to express the sense of tact rather than demonstrative deference, which came to be regarded as stiff and rigid. Later in the $20^{\text {th }}$ century the trends towards emancipation and informalisation continued. New norms encouraged one to behave in a more 'natural' way and with a greater 'ease', whereas too formalised manners came to be experienced as too hierarchical and insincere. Wouters considers that the changes in the power balance were crucial for the informalisation process. As status differentials and social distance between classes, sexes, ethnic and racial groups diminished, it became less acceptable to express the feeling of superiority towards social inferiors, and that was the main reason for the progress of informalisation ${ }^{20}$. At the same time, the process of informalisation did not mean the decrease of selfcontrol by the individuals. The new pattern of self-control requires more reflexivity and greater awareness of oneself and the others. While in the earlier stages of the civilizing process the self-control was a mechanism of the conscience, nowadays it operates through a more reflexive, conscious

${ }^{19}$ Elias, N. (1996) The Germans. New York: Columbia University Press, pp. 73-74.

${ }^{20}$ Wouters, C. (2011) How civilizing processes continued: towards an informalisation of manners and a third nature personality. In: Norman Gabriel and Stephen Mennell (eds.), Norbert Elias and Figurational Research: Processual Thinking in Sociology. Oxford: WileyBlackwell/Sociological Review, p. 150. 
process, when the people are aware that the constraints they take on themselves originate in their social environment ${ }^{21}$.

\section{Norms and the relationships between the established and the outsiders}

The concepts of the established and the outsiders were introduced in the study of the suburb community conducted by Elias in collaboration with John Scotson. These concepts captured the fact that the community was hierarchically ordered: the offices in the administrative and social organisations of the community were held by the representatives of one group of residents, which had lived in the area longer, whereas other groups, more recently settled in the neighbourhood, were excluded from the community offices and the social life of the 'established' group. The higher status group had formed a positive self-image and believed that they had a more ordered and respectful way of life than the other groups, who, as they considered, lived by lower standards. The outsiders were excluded by informal means, such as gossip and rumouring, but these were very effective.

The term 'established' in Elias's theory refers both to social and material success and to the duration of living in the area as a group. When a group lives in a certain place for a long time, which might be several generations, and acquires certain level of well-being, it develops norms of behaviour along with a positive self-image, which strengthen the group cohesion. Material sources of social power, the oldness of the groups, the cohesion, and norms of conduct are linked in Elias's theory: "Greater cohesion, solidarity, uniformity of norms and self-discipline helped to maintain the monopolization, and this in turn helped to reinforce these group characteristics" 22 . Norms of behaviour play an important role in maintaining the power position and the higher status of the group: "The transmission of distinguishing standards usually goes hand in hand with a chance to transmit property of one kind or another..."23 Elias stresses the importance of the age of the group, its oldness, which explains the emergence of particular group norms, as it is a process, which takes time: the "old families" "stand out from others by certain distinguishing

${ }^{21}$ Ibid., p. 157. For the debate about theory of informalisation, see Wouters, C. Mennell, S. (2015) Discussing theories and processes of civilization and informalisation criteriology, Human Figurations, 4:3.

${ }^{22}$ Elias, N., Scotson J. (1994) The Established and the Outsiders. London: Sage Publications, p. 152.

${ }^{23}$ Ibid., p. 151. 
behaviour characteristics which are bred into the individual members from childhood on in accordance with the group's distinguishing tradition"24. Developmental perspective is important here: it takes time for the group to become established and it takes time for the shared norms to form, to be learned and transmitted. Time dimension appears also in Elias's concept of sociological inheritance, which he calls upon: norms of behaviour are transmitted along with the sources of power, be those material possessions or certain skills. These constitute the inheritable chances to exercise power. Norms and power operate in a mutually reinforcing way: greater power produces incentives to form and maintain group solidarity, whereas norms help to mark the insiders and outsiders and to a certain degree to monopolise power resources in possession of the group. These norms need not be "rational" - these could be related to certain manners or tastes; still, the more powerful groups usually follow stricter rules which demands stronger self-control, because this in turn is related to a better developed foresight, a prerequisite for greater success. Observing these group rules, or norms, ease communication and mark out the insiders, while breaking those create barriers inside the group and undermines the group solidarity.

The established groups usually develop positive image of themselves and a negative image of the outsiders. The idea of superiority of a group over others, of its higher value is expressed in the concept of group charisma ${ }^{25}$. The established group praises itself and stigmatises the outsiders as people of lesser human worth. The members of the established group have to pay the price for that in the form of observation of the group norms. At the same time, the non-observance of norms by the outsiders is seen as their lawlessness, disorderliness and anomy. For that reason, the members of the established group tend to avoid the contact with the outsiders for the fear of lowering their normative standards, on maintaining of which depends their self-respect, special grace and virtue of the group ${ }^{26}$.

Elias argued that there may be different power resources on which the superiority-inferiority relations are based, but the capacity of the established group to sustain its cohesion, identity and observe the code of conduct decreases when its power position is weakened: "traditional patterns of restraint, the distinguishing norms of conduct of an old superior

${ }^{24}$ Elias, N., Scotson J. (1994) The Established and the Outsiders. London: Sage Publications, p. 152.

${ }^{25}$ Elias, N. (2009) Group charisma and group disgrace. In: Essays III: On Sociology and the Humanities, Collected Works, vol. 16. Dublin: University College Dublin Press, p. 80.

${ }^{26}$ Introduction by N. Elias to: Elias, N., Scotson J. (1994) The Established and the Outsiders. London: Sage Publications, p. li. 
group are apt to become brittle or even break down when the rewarding self-love, the belief in special charisma of the once-powerful group falters with the decrease of their great power superiority"27. Elias generalises the established-outsiders model and applies to various historical and cultural contexts, such as relationships between aristocracy and common people, ethnic and racial groups and the international relations.

The model of established-outsiders relations has been taken up by a number of sociologists and applied to contemporary social problems. It has been used in the studies of the relations between the immigrants and local population, the issues of discrimination, exclusion, stigmatisation and reproduction of inequalities ${ }^{28}$. Stephen Mennell has applied the concept in his study of the civilizing process in the USA, and to analyse American foreign policy ${ }^{29}$. Generally, these studies confirm the ideas put forward by Elias and Scotson: the established groups seek to preserve their advantaged position vis-à-vis the outsiders by using ideological tools, such as dissemination of negative stereotypes, gossips or passing of false information, and the policy of exclusion by mobilising their social capital. Still, it can be noted that contemporary studies employing the framework of established-outsiders relations concentrate mostly on power and inclusionexclusion problem, but pay less attention to the issue of norms. Also, there is missing a discussion about the overarching norms applicable for both the established and the outsiders and what makes these norms valid.

\section{The duality of norms and international relations}

Elias was among the first sociologists who called attention to the necessity of considering relationships within large social units, such as states, as well as between them; he also regarded these two kinds of relationships as being governed by substantially different norms. In "The Civilizing Process", he described the military competition between feudal lords as 'elimination struggle'. The competing lords strived to achieve greater power potential over against the others. The stronger lords survived, the weaker were eliminated or subordinated. The same happens between other kinds of social units, the tribes or the states.

${ }^{27}$ Introduction by N. Elias to: Elias, N., Scotson J. (1994) The Established and the Outsiders. London: Sage Publications, p. xlv.

${ }^{28}$ Loyal, S. (2011) A land of hundred thousand welcomes? Understanding established and outsiders relations in Ireland. In: Norman Gabriel and Stephen Mennell (eds.), Norbert Elias and Figurational Research: Processual Thinking in Sociology. Oxford: Wiley-Blackwell/ Sociological Review, pp. 181-201; Petintseva, O. (2015) Approaching new migration through Elias's 'established and 'outsiders' lens, Human Figurations, 4:3.

${ }^{29}$ Mennell, S. (2007) The American Civilizing Process. Cambridge: Polity Press. 
Relationships between social units characterised by mutual distrust and recourse to force is a general phenomenon in human history: "Mutual distrust between human groups, the unbridle use of violence in their relations with each other so long as they expected advantage and were not afraid of retaliation, has been very general, one might almost say normal, throughout the ages" 30 . Distrust and violence are characteristic of relationships between survival units because, according to Elias, in the last instance, there is no authority above them, which can enforce any rule or norm regulating their relationships: "There is no law governing the relations between states of the kind that is valid within them. There is no all-embracing power apparatus that could back up such an international law"31. The relationships within survival units, such as states, are formed on the premise that there is a higher authority, which can resolve conflicts, if necessary, by applying physical force. Accordingly, people within states behave in a more restrained way, exercising greater self-control, foresight and consideration of others. People therefore can develop more amicable, peaceful, 'civilized' relationships with each other. More stable self-control in relations among people develops along with suppression of violence by institutional means; this is what Elias called the civilizing process. He retained his views on the different nature of international and domestic relationships in his late works and criticised the theories and conceptions, which pictured social norms of one society as an integrated system. Elias pointed out that norms have integrating, as well as dividing and separating functions $^{32}$. In the relationships among citizens, there is one moral code: people are taught that it is wrong to kill, terrorise others, steal and cheat. However, at the same time all that is permitted or even endorsed in order to defend one's survival unit or in attacking another survival unit ${ }^{33}$. Therefore, the moral code is split and there exists the duality of norms. The concept of the duality of norms can provide theoretical account of the practice of 'double standards' in contemporary politics and mass media.

Researchers distinguish two themes in Elias's texts about international relations. One theme is associated with the idea of survival units opposing each other and trying to secure their existence under conditions of absence of overarching monopoly on the use of violence. There relations are characterised by fragile peace, mutual suspicion and at times flaring conflicts. Most powerful states strive to achieve hegemonic position for security. The civilizing process therefore contained a paradox: greater

\footnotetext{
${ }^{30}$ Elias, N. (1996) The Germans. New York: Columbia University Press, p. 137.

${ }^{31}$ Elias, N. (2000) The Civilizing Process. Oxford: Blackwell, p. 235.

32 Elias, N. (1996) The Germans. New York: Columbia University Press, p. 158-159.

${ }^{33}$ Ibid., p. 161.
} 
pacification within states led to more violence in relations between states. Nationally anchored habitus prevails in framing the interests of states in foreign policy. There are similarities between Elias's conceptions and modern theories in the discipline of international relations, for example in the view of the difference between the domestic order governed by laws and the anarchy of the international relations, the predisposition of the states to become entangled in spiralling geopolitical competition ('doublebind' in Elias's terms), the acknowledgement that the international peace largely rests on the balance of power - the external constraint that the states impose on each other ${ }^{34}$. There are discussions of contemporary problems in international relations, such as duality of norms, double-bind and established-outsiders relations in world politics ${ }^{35}$.

Another theme is connected with Elias's concerns about the trajectory of human development and the future of humanity. He pointed out that one could observe the growing interdependence between national survival units thanks to economic interconnectedness and the global character of problems such as ecology and threat of nuclear war. Consequently, the nation state loses its role as survival unit and it passes to the whole humanity, which is becoming the real survival unit. Elias foresaw the possibility that there could be political integration beyond the nationstate. This post-national unit of integration would comprise a number of states or all states of the globe. The civilizing process on a global scale may lead to the widening of the circle of mutual identification among the international actors, they may acquire stronger repugnance to violence and the norms prevalent in international relations will chang $\mathrm{e}^{36}$. In that case, the global humanity, by gaining greater control of their emotional impulses and mastering greater detachment in international matters, might voluntarily renounce the military means of obtaining security and evolve in a kind of pacified confederation of states ${ }^{37}$. However, the path towards

${ }^{34}$ Linklater, A. (2011) Process sociology and international relations. In: Norman Gabriel and Stephen Mennell (eds.), Norbert Elias and Figurational Research: Processual Thinking in Sociology. Oxford: Wiley-Blackwell/Sociological Review; Hobson, J. M. (2012) Reconfiguring Elias: Historical Sociology, the English School, and the Challenge of International Relations, Human Figurations, 1:2.

${ }^{35}$ Mennell, S. (2012) Realism and Reality Congruence: Sociology and International Relations, Human Figurations, Vol. 1 (2); Mennell, S. (2014) Globalisation and the 'American dream', Human Figurations, 3:2.

${ }^{36}$ Linklater, A. (2011) Process sociology and international relations. In: Norman Gabriel and Stephen Mennell (eds.), Norbert Elias and Figurational Research: Processual Thinking in Sociology. Oxford: Wiley-Blackwell/Sociological Review, pp. 48-64.

${ }^{37}$ Elias, N. (2010) Humana Conditio. In: The Loneliness and of the Dying and Humana Conditio, Collected Works, vol. 6. Dublin: University College Dublin Press, p. 146. 
such higher level of integration will be difficult and uncertain, because the national habitus has a 'drag effect' and would inhibit the development of cosmopolitan identities and a wider sense of responsibility ${ }^{38}$.

\section{Norms, religion and ideological power}

As pointed out above, Elias considered power relations arising from human interdependencies as generally determining the norms prevalent in society. Accordingly, he attributed marginal role to religion or ideology in the civilizing process. Commenting on the mores of the middle ages in Europe, he wrote: "Religion, the belief in the punishing or rewarding omnipotence of God, never has in itself a civilizing of affect-subduing effect. On the contrary, religion is always exactly as civilized as the society or class which upholds it" 39 . Mennell acknowledges that Elias gave little credence to the civilizing influence of religious ideas and regarded the clerics in this respect as no different from secular lords ${ }^{40}$. In his late book "The Germans" Elias is less categorical. He concedes that sometimes inter-group violence in human history could be tempered by belief in superhuman agency ${ }^{41}$. At the same time, he notes that such beliefs can provoke even greater suspicion and violence. He believes that religious organisations with their major power resources could exert pacifying influence on human behaviour. "Still, it was probably not entirely accidental that in Europe, at the time when the most powerful organisation of superhuman beliefs, the medieval church, was losing a considerable part of its dominions, and with it the monopoly of thought-control in Western European societies, understanding of the matter in which the ruling groups of different territories related to each other became secularized" 42 . When the authority of Catholic Church was undermined, the relations between the political units in Western Europe became more unrestrained and ruthless. Nevertheless, the power to influence social relations, for Elias, rests not in religious doctrines or their individual promulgators, but rather in religious organisation.

In this position, Elias runs counter to the traditions of both Max Weber and Emile Durkheim, who regarded religion as an important source of norms. It is well known that Weber considered religion as a sphere of

\footnotetext{
${ }^{38}$ Delmotte, F. (2012) About Post-National Integration in Norbert Elias's Work: Towards a Socio-Historical Approach, Human Figurations, 1:2.

${ }^{39}$ Elias, N. (2000) The Civilizing Process. Oxford: Blackwell, p. 169.

${ }^{40}$ Mennell, S. (2007) The American Civilizing Process. Cambridge: Polity Press, p. 268.

${ }^{41}$ Elias, N. (1996) The Germans. New York: Columbia University Press, p. 137.

${ }^{42}$ Ibid., p. 138.
} 
thought and action possessing autonomy relatively to other domains of social action. Different religious doctrines channelled the activity of individuals and groups into different directions, more or less otherworldly. Religious doctrines moulded the ways of life, the patterns of behaviour of their practitioners. For example, according to Weber, rationalisation of the conception of the divine at the birth of monotheistic religions transformed the behaviour of believers "into a milder, but more permanent habitus, and moreover one that was consciously possessed"43; Protestantism imposed on its followers steady self-control and provided economic activity with the sense of purpose, which was conducive to the rise of capitalism ${ }^{44}$.

S. N. Eisenstadt, drawing on the works of Weber, argued that charisma as capability to create existential meaning is a constituent element in institution building ${ }^{45}$. Institutions have two dimensions: organisational and symbolic. Charismatic personalities, or 'institutional entrepreneurs', have been able to reorganise symbolic and cognitive orientations of their followers, to formulate new collective goals, propound new norms and inject those in the organisational forms. As he shows on the examples from Weber's writings and in his own research, charismatic activities have influenced throughout history various institutional spheres, including politics, law, religion and the economy ${ }^{46}$. Michael Mann in his extensive historical-sociological study of human societies put forward the concept of ideological power as being relatively independent from other sources of power - military, economic and political. The basis of ideological power, he argues, lies in the need for normative regulation and meaning. He mentions examples, which point to the autonomous nature of ideological doctrines and religious practices and their influence on social order. The attractiveness of early Christianity was in its capacity to create a normative community, the ecclesia, for the people of the Roman Empire who were excluded from the official cultural life. Christian communities existed for three centuries without the buttress of the state and in spite of persecutions. In the medieval period, the significance of Catholic Church was in preservation of literary culture and providing a degree of normative pacification in Europe across the territorial units of secular and ecclesiastic

\footnotetext{
${ }^{43}$ Weber, M. (1965) The Sociology of Religion. London: Methuen \& Co Ltd., p. 158.

${ }^{44}$ Weber, M. (1958) The Protestant Ethic and the Spirit of Capitalism. New York: Charles Scribner's Sons.

${ }^{45}$ Eisenstadt, N. S. (1968) Introduction. Charisma and Institution Building: Max Weber and Modern Sociology. In: N. S. Eisenstadt (ed.) Max Weber. On Charisma and Institution Building. Chicago: University of Chicago Press.

${ }^{46}$ Weber, M. (1968) On Charisma and Institution Building. Ed. by S. N. Eisenstadt. Chicago: University of Chicago Press; Eisenstadt, N. S. (2003) Comparative Civilizations and Multiple Modernities. Vols. 1 and 2. Leiden: Brill.
} 
lords, which contributed to maintenance of translocal communication and economic ties ${ }^{47}$.

Law historian Harold Berman argued that theological conceptions of Christianity and Greek philosophy strongly influenced the formation of legal tradition in Europe. Especially this influence could be seen in Western Europe, after rediscovery of Roman law in $11^{\text {th }}$ century. Scholastics generalised the norms of Roman law, systematised them, developed the idea of natural law to which customary and statute law had to be subordinated, advanced methods of legal reasoning and formulated fundamental principles and concepts of law. Subsequently, there emerged understanding of law as a particular sphere of theory and practice relatively autonomous from politics and religion ${ }^{48}$.

All these examples indicate that explanation of the origins of norms in terms of 'power' as understood by Elias, is not sufficient ${ }^{49}$. A more complete explanation strategy should take into account ideological, religious and cultural influences understood as autonomous forces capable of changing normative regulation of societies.

\section{Conclusion}

Studies in the perspective of figurational sociology show that the concept of norms is a complex one. Its content is not exhausted by a simple functionalist notion that norms are generalised behavioural expectations serving the purpose of prevention of disappointment of expectations of social actors ${ }^{50}$. Norms are in a complex way interweaved with the power structure of society, with the matters of social prestige and self-image, state formation and the civilizing process. The actual observation of norms is dependent upon the existence of an effective external controlling agency and the in-built, acquired through socialisation self-control of the individuals. Norms governing domestic relations are different from norms prevalent in international arena. Norms reflect not only the power balance between the groups within society, but also the power position of the particular survival unit in relation to other survival units. Studies

\footnotetext{
${ }^{47}$ Mann, M. (2013) The Sources of Social Power. Vol.1. Cambridge: Cambridge University Press, Chapter 10.

${ }^{48}$ Berman, H. (1983) Law and Revolution. The Formation of the Western Legal Tradition. Cambridge, Mass.: Harvard University Press.

${ }^{49} \mathrm{~J}$. Goudsblom attempted to defend Elias's position on religion, in author's view, not quite convincingly (Goudsblom, J. (2003) Christian Religion and the European Civilising Process: The Views of Norbert Elias and Max Weber Compared in the Context of the Augustinian and Lucretian Traditions, Irish Journal of Sociology. Vol. 12(1), pp. 24-38).

${ }^{50}$ Luhmann, N. (1985) A sociological theory of law. London: Routledge \& Kegan Paul.
} 
in figurational perspective produced a stock of sociological findings and it appears to be more fruitful to search into the patterns of interrelations between norms, power and meaning in various historical contexts than to postulate in theory their inseparable interconnectedness.

The question of the origin of norms in figurational sociology, however, is controversial. The denial that norms can derive from charismatic, religious sources contradicts other sociological schools. Works by Weber, Berman, Eisenstadt and Mann point out that religious or metaphysical doctrines can direct and shape human behaviour, establish norms of interaction, and organise collectivities. The problem of the relation of the 'ideal' factors to the genesis of norms has not yet been dealt with directly by the scholars working within figurational perspective. It is rather common either to downplay the impact of worldviews and ideas in comparison to the significance of 'power' or to reformulate the question in terms of occupational specialisations. Fuller integration of ideological factors can enrich the theoretical and methodological tools of figurational sociology and result in constructing of a more powerful explanatory framework.

\section{REFERENCES}

\section{Printed sources}

1. Berman, H. (1983) Law and Revolution. The Formation of the Western Legal Tradition. Cambridge, Mass.: Harvard University Press.

2. Dunning, E., Hughes, J. (2013) Norbert Elias and Modern Sociology. London: Bloomsbury.

3. Eisenstadt, N. S. (1968) Introduction. Charisma and Institution Building: Max Weber and Modern Sociology. In: N. S. Eisenstadt (ed.) Max Weber. On Charisma and Institution Building. Chicago: University of Chicago Press.

4. Eisenstadt, N. S. (2003) Comparative Civilizations and Multiple Modernities. Vols. 1 and 2. Leiden: Brill.

5. Elias, N. (1978) What is Sociology? New York: Columbia University Press.

6. Elias, N. (1996) The Germans. New York: Columbia University Press.

7. Elias, N. (2000) The Civilizing Process. Oxford: Blackwell.

8. Elias, N. (2009) Group charisma and group disgrace. In: Essays III: On Sociology and the Humanities, Collected Works, vol. 16, Dublin: University College Dublin Press, pp. 73-81.

9. Elias, N. (2009) The changing balance of power between the sexes - a processsociological study: example of the ancient Roman state. In: Essays III: On Sociology and the Humanities, Collected Works, vol. 16, Dublin: University College Dublin Press, pp. 240-265.

10. Elias, N. (2009) The retreat of sociologists into the present. In: Essays III: On Sociology and the Humanities, Collected Works, vol. 16, Dublin: University College Dublin Press, pp. 107-126. 
11. Elias, N. (2010) Humana Conditio: Observations on the Development of Humanity on the Fortieth Anniversary of the End of a War (8 May 1985). In: The Loneliness of the Dying and Humana Conditio, Collected Works, vol. 6, Dublin: University College Dublin Press, pp. 77-170.

12. Elias, N., Scotson, J. (1994) The Established and the Outsiders. London: Sage Publications.

13. Giddens, A. (1979) Central problems in social theory. Berkeley and Los Angeles: University of California Press.

14. Giddens, A. (1986) The Constitution of Society. Berkeley and Los Angeles: University of California Press.

15. Giddens, A. (1992) The Nation-State and Violence. Cambridge: Polity Press.

16. Giddens, A. (1995) A contemporary critique of historical materialism. Second edition. Stanford: Stanford University Press.

17. Goudsblom, J. (2003) Christian Religion and the European Civilising Process: The Views of Norbert Elias and Max Weber Compared in the Context of the Augustinian and Lucretian Traditions, Irish Journal of Sociology. Vol. 12(1), pp. 24-38.

18. Linklater, A. (2011) Process sociology and international relations. In: Norman Gabriel and Stephen Mennell (eds.), Norbert Elias and Figurational Research: Processual Thinking in Sociology. Oxford: Wiley-Blackwell/Sociological Review, pp. 48-64.

19. Loyal, S. (2011) A land of hundred thousand welcomes? Understanding established and outsiders relations in Ireland. In: Norman Gabriel and Stephen Mennell (eds.), Norbert Elias and Figurational Research: Processual Thinking in Sociology. Oxford: Wiley-Blackwell/Sociological Review, pp. 181-201.

20. Luhmann, N. (1985) A sociological theory of law. London: Routledge \& Kegan Paul.

21. Mann, M. (2013) The Sources of Social Power. Vol.1. Cambridge: Cambridge University Press.

22. Mennell, S. (2007) The American Civilizing Process. Cambridge: Polity Press.

23. Quilley, S., Loyal, S. (2005) Eliasian Sociology as a 'Central Theory' for the Human Sciences, Current Sociology. Vol. 53(5) pp. 807-828.

24. Weber, M. (1958) The Protestant Ethic and the Spirit of Capitalism. New York: Charles Scribner's Sons.

25. Weber, M. (1965) The Sociology of Religion. London: Methuen \& Co Ltd.

26. Weber, M. (1968) On Charisma and Institution Building. Ed. by S. N. Eisenstadt. Chicago: University of Chicago Press.

27. Wouters, C. (2011) How civilizing processes continued: towards an informalization of manners and a third nature personality. In: Norman Gabriel and Stephen Mennell (eds.), Norbert Elias and Figurational Research: Processual Thinking in Sociology. Oxford: Wiley-Blackwell/Sociological Review, pp. 140-159.

Internet sources: online journal Human Figurations

28. Petintseva, O. (2015) Approaching new migration through Elias's 'established and 'outsiders' lens, Human Figurations, 4: 3 http://hdl.handle.net/2027/ spo.11217607.0004.304. 
29. Hobson, J. M. (2012) Reconfiguring Elias: Historical Sociology, the English School, and the Challenge of International Relations, Human Figurations, 1: 2 http://hdl. handle.net/2027/spo.11217607.0001.206.

30. Mennell, S. (2012) Realism and Reality Congruence: Sociology and International Relations, Human Figurations, 1:2 http://hdl.handle.net/2027/spo.11217607.0001.210.

31. Mennell, S. (2014) Globalisation and the 'American dream', Human Figurations, 3: 2 http://hdl.handle.net/2027/spo.11217607.0003.206.

32. Delmotte, F. (2012) About Post-National Integration in Norbert Elias's Work: Towards a Socio-Historical Approach, Human Figurations, 1: 2 http://hdl.handle. net/2027/spo.11217607.0001.209.

33. Wouters, C., Mennell, S. (2015) Discussing theories and processes of civilisation and informalisation criteriology, Human Figurations, $4: 3$ http://hdl.handle.net/2027/ spo.11217607.0004.302. 